\title{
PENGARUH MODEL PEMBELAJARAN KOOPERATIF SCRIPT TERHADAP HASIL BELAJAR ILMU PENGETAHUAN ALAM
}

\author{
Ni Nyoman Ayu Ashari Aprilya Putri \\ Program Studi Pendidikan Guru Sekolah Dasar, Universitas Pendidikan Ganesha \\ ashari.ayu14@yahoo.com
}

\begin{abstract}
Abstrak
Penelitian ini bertujuan untuk mengetahui perbedaan hasil belajar ilmu pengetahuan alam antara siswa yang dibelajarkan dengan model pembelajaran Kooperatif Script dan siswa yang dibelajarkan dengan pembelajaran langsung pada siswa kelas V SD di Gugus IV Kecamatan Rendang Tahun Pelajaran 2017/2018. Jenis penelitian ini adalah eksperimen semu dengan rancangan non equivalent post-test only control group design. Populasi dalam penelitian ini adalah seluruh siswa kelas V SD di Gugus IV Kecamatan Rendang Tahun Ajaran 2017/2018 dengan jumlah siswa 159 orang. Sampel penelitian adalah siswa kelas V SD Negeri 4 Pempatan sebagai kelas eksperimen dengan jumlah siswa 28 orang dan SD Negeri 8 Pempatan sebagai kelas kontrol dengan jumlah siswa 26 orang. Data hasil belajar dikumpulkan dengan menggunakan tes objektif. Data dianalisis dengan menggunakan uji-t. Hasil penelitian ini menunjukkan terdapat perbedaan hasil belajar ilmu pengetahuan alam antara kelompok siswa yang dibelajarkan dengan model pembelajaran Kooperatif Script dan kelompok siswa yang dibelajarkan dengan menggunakan pembelajaran langsung, dengan perhitungan $t_{\text {hitung }}=5,53>t_{\text {tabel }}=2,021$ dengan taraf signifikansi 5\%. Adanya perbedaan yang signifikasn menunjukkan bahwa model pembelajaran Kooperatif Script berpengaruh terhadap hasil belajar ilmu pengetahuan alam siswa dibandingkan dengan pembelajaran langsung.
\end{abstract}

Kata Kunci: model pembelajaran kooperatif script, hasil belajar ilmu pengetahuan alam

\begin{abstract}
This study aimed to determine the difference of science learning outcomes between students who were taught by The Learning Model of Cooperative Script and student who were taught with direct learning on fifth grade students of elementary school in Gugus IV Rendang district in academic year 2017/2018. This type of research is quasi experiment with non equivalent design post-test only control group design. The research population was all fifth grade students of elementary school in Gugus IV Rendang District in academic year 2017/2018 that consisted of 159 students. The sampel of the research was fifth grade students of SD Negeri 4 Pempatan as the experimental class that consisted of 28 students and the students of SD Negeri 8 Pempatan as the control class that consisted of 28 students. The data of learning result was collected by using objective test. The data was analyzed using t-test. The results of this study indicated that there were difference in science learning outcomes between the group of students who were taught by Cooperative Learning Model Script and the group of students who were taught by using direct learning through the calculation showed that t-calculation $=5,53>\mathrm{t}$-tabel $=2,021$ with $5 \%$ significance level. a significant difference indicateds science learning outcomes compared to the students who were taught with direct learning.
\end{abstract}

Keywords: The Learning Model of Cooperative Script, Science learning outcomes

\section{Pendahuluan}

Pendidikan pada dasarnya merupakan proses untuk membantu manusia dalam mengembangkan potensi diri yang dimiliki oleh seseorang sehingga mampu menghadapi setiap perubahan-perubahan yang terjadi. Pendidikan mempunyai peranan penting bagi kelangsungan hidup manusia. Dengan adanya pendidikan mampu membuat seseorang menjadi cerdas, kreatif dan bertanggung jawab sehingga dengan adanya pendidikan mampu menciptakan manusia Indonesia yang seutuhnya. Pendidikan sangatlah perlu untuk dikembangkan sehingga kualitas SDM bisa terjamin. Dengan adanya pendidikan yang berkualitas akan mampu meningkatkan kecerdasan suatu bangsa. Selain itu pendidikan merupakan suatu usaha untuk mencapai dan mengarahkan seseorang untuk menuju tahap pendewasaan dengan memberikan ilmu pengetahuan, melatih berbagai keterampilan, menanamkan nilai-nilai yang baik, serta sikap yang baik. Banyak upaya yang sudah dilakukan dalam pendidikan, di antaranya yaitu melakukan pengembangan maupun penyempurnaan kurikulum yang dilakukan secara bertahap, konsisten dan disesuaikan dengan perkembangan dan kemajuan ilmu pengetahuan dan teknologi.

Pendidikan di sekolah tidak terlepas dari proses pembelajaran dan interaksi antara guru dengan siswa. Proses pembelajaran merupakan suatu proses yang sangat rumit karena tidak sekedar menerima informasi yang diberikan oleh guru, tetapi juga melibatkan berbagai kegiatan dan tindakan yang dilakukan untuk memperoleh hasil belajar yang baik. Dalam proses belajar mengajar, guru merupakan kunci utama dalam meningkatkan mutu dan kualitas pendidikan. Guru mempunyai tanggung jawab untuk mengatur, mengarahkan, dan menciptakan suasana yang nyaman dan menyenangkan sehingga mendorong siswa untuk ikut berfartisipasi aktif dalam 
mengikuti proses belajar mengajar di dalam kelas. Dalam hal ini cara guru dalam mengajar akan sangat berpengaruh terhadap siswa. Oleh karena itu seorang guru harus bisa menyesuaikan cara mengajar dengan kondisi siswa, apalagi setiap siswa memiliki cara belajar yang berbeda karena setiap siswa memiliki karakteristik yang berbeda-beda pula.

Syaifurahman (2013) menyatakan bahwa pembelajaran yang berkualitas sangat tergantung dari motivasi siswa dan kreatifitas guru. Pembelajaran yang mempunyai motivasi tinggi dan di tunjang dengan guru yang mampu memfasilitasi motivasi tersebut akan membawa pada keberhasilan pencapaian target belajar. Target belajar dapat diukur melalui perubahan sikap dan kemampuan siswa melalui proses belajar. Desain pembelajaran yang baik, ditunjang fasilitas yang memadai, ditambah dengan kreatifitas guru akan membuat siswa lebih mudah mencapai tujuan belajar.

Mata pelajaran ilmu pengetahuan alam merupakan salah satu mata pelajaran pokok yang ada di sekolah dasar. Ilmu pengetahuan alam membahas tentang gejala-gejala alam yang disusun secara sistematis yang didasarkan pada hasil percobaan dan pengamatan yang dilakukan oleh manusia (Samatowa, 2010). Dengan pemahaman terhadap materi ilmu pengetahuan alam siswa diharapkan mampu berpikir secara kritis dalam menyikapi peristiwa-peristiwa yang terjadi di lingkungan sekitarnya. Namun kenyataannya di lapangan pembelajaran IPA masih berorientasi pada guru dan kurang memberi pemahaman dengan jelas kepada siswa tentang materi pembelajaran.

Berdasarkan hasil observasi yang dilakukan, mata pelajaran ilmu pengetahuan alam di sekolah dasar masih belum optimal. (1) saat proses belajar mengajar sedang berlangsung, guru kurang melibatkan siswa untuk aktif dalam kegiatan pembelajaran, (2) kurangnya pemahaman guru terhadap model-model pembelajaran. Hal ini nampak jelas karena guru cenderung menggunakan metode ceramah selama proses pembelajaran berlangsung. (3) dalam mengerjakan soal guru belum menggunakan pengerjaan secara berkelompok sehingga interaksi antar siswa sangat kurang, (4) kurangnya percaya diri siswa saat menyampaikan pendapat. Selain melakaukan observasi juga dilakukan wawancara dengan guru kelas V SDN Gugus IV Kecamatan Rendang dan diperoleh hasil bahwa saat proses belajar mengajar siswa kurang percaya diri dalam menyampaikan ide atau pendapat saat proses pembelajaran berlangsung dan dari beberapa mata pelajaran yang ada di sekolah nilai mata pelajaran ilmu pengetahuan alam masih berada di bawah KKM yang sudah ditentukan.

Kedua kemampuan berkomunikasi siswa rendah. Metode ceramah yang selalu digunakan guru setiap pembelajaran juga menyebabkan kemampuan berkomunikasi siswa rendah, hal tersebut terlihat saat proses pembelajaran yang mana siswa kurang aktif bertanya maupun memberikan pendapat. Ketiga, siswa jarang bertukar informasi dengan teman sebangku maupun kelompoknya. Dalam pembelajaran ilmu pengetahuan alam yang dilaksanakan, siswa juga jarang bekerja kelompok maupun berdiskusi dengan teman sebangkunya. Hal tersebut mengakibatkan pengetahuan yang dimiliki siswa tentang materi yang dipelajari hanya sebatas pengetahuan yang dimilikinya, jadi tidak ada pengetahuaan baru yang mereka dapatkan selain dari buku maupun dari guru ketika menjelaskan materi di depan kelas. Dari delapan sekolah yang ada di Gugus IV Kecamatan Rendang dengan jumlah siswa sebanyak 159 orang, adapun siswa yang sudah mencapai KKM yaitu sebanyak 56 orang dan siswa yang belum mencapai KKM yaitu sebanyak 103 orang.

Kondisi yang demikian apabila dibiarkan akan berdampak kurang optimal terhadap kualitas pembelajaran ilmu pengetahuan alam di SD Gugus IV Kecamatan Rendang. Dengan demikian sangat penting menerapkan model-model pembelajaran yang bervariasi sehingga dapat melibatkan siswa secara aktif dalam proses belajarmengajar. Proses pembelajaran dapat dapat dilakukan dengan model pembelajaran yang sesuai dengan kondisi yang dialami oleh siswa dan kurikulum yang ditetapkan pada saat ini. Salah satu solusi yang ditawarkan adalah dengan menerapkan model pembelajaran Kooperatif Script. Kooperatif Script merupakan model pembelajaran dimana siswa bekerja secara berpasangan dan bergantian secara lisan dalam mengikhtisarkan bagian-bagian materi yang dipelajari (Huda, 2014). Strategi ini ditujukan untuk membantu siswa berpikir secara sistematis dan berkonsentrasi pada materi pelajaran. Siswa juga dilatih untuk saling bekerja sama satu sama lain dalam suasana yang menyenangkan. Pembelajaran ilmu pengetahuan alam dengan menggunakan model ini tentunya cocok diterapkan. Seperti yang diketahui dalam pembelajaran ilmu pengetahuan alam siswa di tuntut untuk berpikir kritis. Berpikir kritis (critical thingking) merupakan keterampilan yang penting untuk dikembangkan oleh setiap individu dalam mempersiapkan diri dalam bersaing sebagai sumber daya manusia yang unggul (Suranata dan Susiani, 2017).

Dari permasalahan di atas perlu untuk mengetahui pengaruh model pembelajaran Kooperatif Script terhadap hasil belajar ilmu pengetahuan alam Siswa Kelas V di SD Gugus IV Kecamatan Rendang Tahun pelajaran 2017/2018.

Adapun tujuan dari penelitian ini adalah untuk mengetahui pengaruh model pembelajaran kooperatif script terhadap hasil belajar ilmu pengetahuan alam kelompok siswa yang dibelajarkan dengan menggunakan model pembelajaran Kooperatif Script dengan kelompok siswa yang dibelajarkan menggunakan pembelajaran langsung pada siswa kelas V SD di Gugus IV Kecamatan Rendang tahun pelajaran 2017/2018. 


\section{Metode}

Tempat pelaksanaan penelitian dilaksanakan di Gugus IV Kecamatan Rendang, Kabupaten Karangasem pada rentang waktu semester II (genap) tahun pelajaran 2017/2018. Jenis penelitian ini adalah penelitian eksperimen semu (Quasi Eksperiment). Penelitian eksperimen semu, penempatan subjek ke dalam kelompok yang dibandingkan tidak dilakukan secara acak melainkan sudah ada dalam kelompok. Rancangan penelitian yang digunakan dalam penelitian ini adalah post-test only control group design.

Populasi dalam penelitian ini adalah seluruh siswa kelas V di Gugus IV Kecamatan Rendang tahun ajaran 2017/2018 yang terdiri dari SD N 1 Pempatan, SD N 2 Pempatan, SD N 3 Pempatan, SD N 4 Pempatan, SD N 5 Pempatan, SD N 6 Pempatan, SD N 7 Pempatan, SD N 8 Pempatan dengan jumlah keseluruhan siswa 159 orang.

Pengambilan sampel dalam penelitian ini menggunakan teknik group random sampling. Menurut Suewarno (dalam Agung, 2014:164) "teksni group random sampling adalah suatu cara pengambilan sampel secara acak, sampel diambil berdasarkan kelas bukan individu, setiap anggota populasi mempunyai kesempatan sama untuk dipilih menjadi sampel". kedelapan sekolah yang setara selanjutnya akan diadakan pengundian untuk menentukan dua kelas yaitu sebagai sampel. setelah mengetahui dua kelompok sampel dilakukan pengundian kembali untuk menentukan kelas eksperimen dan kelas kontrol. Hasil pengundian tersebut adalah SD Negeri 4 Pempatan sebagai kelas eksperimen dan SD Negeri 8 Pempatan sebagai kelas kontrol.

Metode pengumpulan data dalam penelitian ini adalah metode tes. Instrumen yang digunakan untuk mengumpulkan data hasil belajar ilmu pengetahuan alam adalah tes pilihan ganda. Tes yang dibuat berdasarkan jenjang taksonomi bloom. Bloom (dalam Antara, 2011) mengungkapkan tingkatan kognitif yang terdiri dari enam tingkatan yaitu mengingat (C1), memahami (C2), menerapkan (C3), menguraiakn/analisis (C4), menggabungkan/sintesis (C5), menilai/evaluasi (C6). Taksonomi Bloom kemudian direvisi oleh Anderson dengan ranah kognitif yang terdiri dari mengingat (C1), memahami (C2), menerapkan (C3), menganalisis (C4), menilai (C5), dan menciptakan (C6). Untuk pemilihan setiap ranah disesuaikan dengan masing-masing indikator pada kisi-kisi instrument penelitian.

Analisis data statistik yang digunakan dalam penelitian ini yaitu menggunakan statistik deskriptif (mean, median, modus dan standar deviasi) dan statistik inferensial (uji normalitas, uji homogenitas dan hipotesis).

\section{Hasil dan Pembahasan}

Data hasil belajar Ilmu Pengetahuan Alam (IPA) siswa kelompok eksperimen dapat dilihat skor post-test dari 28 siswa menunjukkan bahwa skor tertinggi adalah 27 dan skor terendah adalah 11. Hasil perhitungan mendeskripsikan mean (M), median (me), modus (mo), data hasil belajar ilmu pengetahuan alam kelompok eksperimen diantaranya: mean $=20,03$, median $=20,7$, modus $=22,05$, sedangkan data hasil belajar Ilmu Pengetahuan Alam siswa kelompok kontrol dapat dilihat dari skor post-test dari 26 siswa menunjukkan bahwa skor tertinggi adalah 23 dan skor terendah adalah 6. Hasil perhitungan mendeskripsikan mean (M), median (me), modus (mo), data hasil belajar ilmu pengetahuan alam kelompok eksperimen diantaranya: mean = 13,96 median $=13,93$ modus $=13,9$. Perbandingan nilai dapat dilihat pada tabel 1 di bawah ini.

Tabel 1.Perbandingan Mean, Median, Modus Hasil Belajar Ilmu Pengetahuan Alam Kelompok Eksperimen dan Kelompok Kontrol

\begin{tabular}{lcc}
\hline \multicolumn{1}{r}{ Variabel } & Kelompok Eksperimen & Kelompok Kontrol \\
\hline Mean & 20,03 & 13,96 \\
Median & 20,7 & 13,93 \\
Modus & 22,05 & 13,9 \\
\hline
\end{tabular}

Berdasarkan tabel di atas, dapat dilihat bahwa pada kelompok eksperimen diketahui modus lebih besar dari median dan median lebih besar dari mean (Mo $>\mathrm{Md}>\mathrm{M}$ ), sehingga kurva yang terbentuk adalah kurva juling negatif yang artinya sebagian skor cenderung tinggi. Hal ini dapat dilihat pada gambar grafik di bawah ini. 


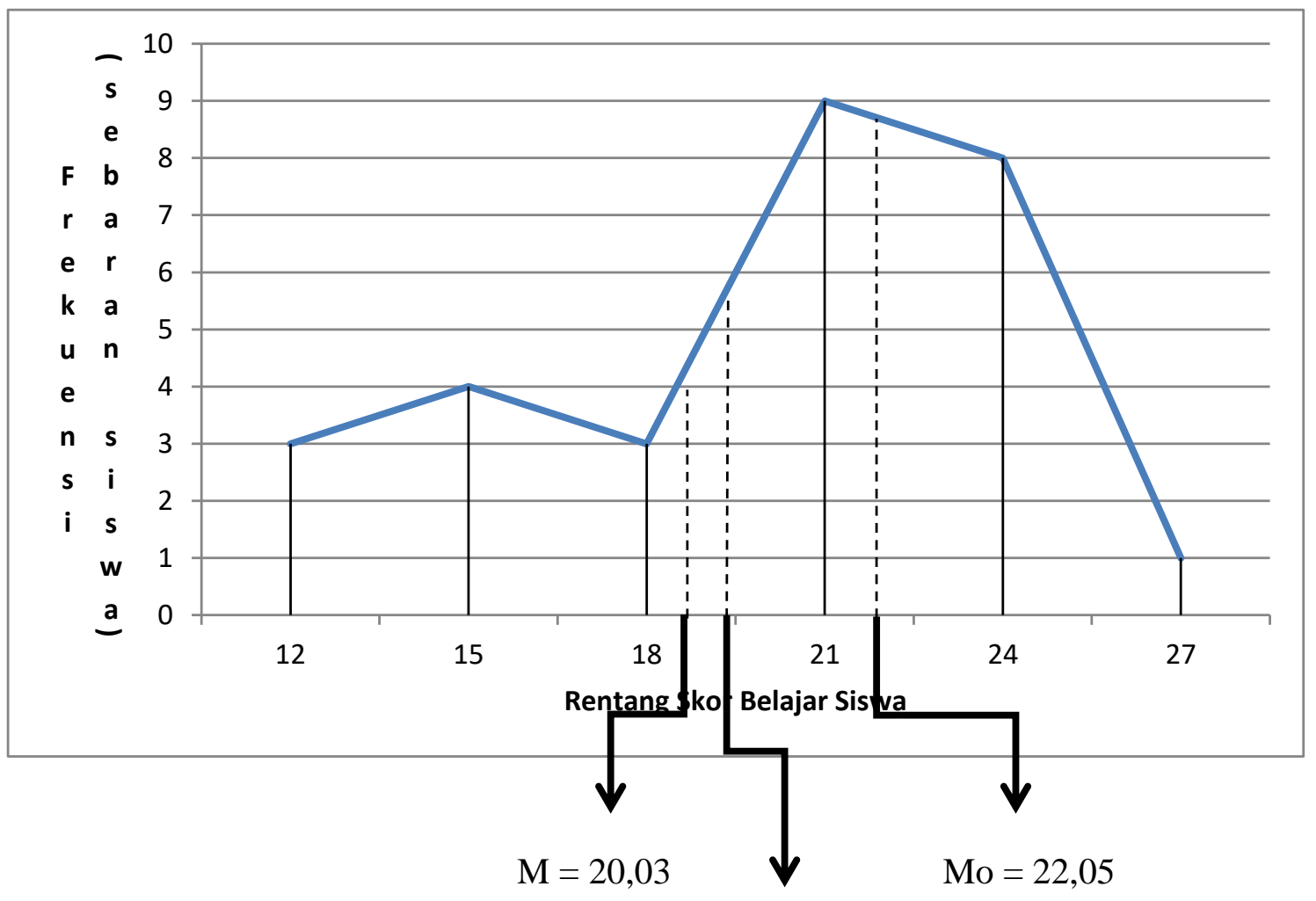

$$
\mathrm{Md}=20,7
$$

Gambar 1. Poligon Data Hasil Belajar Kelompok Eksperimen

Sedangkan dilihat pada kelompok kontrol yaitu Modus $<$ Median $<$ Mean ( Mo $<$ Md $<$ M).

Dengan demikian maka kurve juling yang terbentuk adalah kurve juling positif, yang berarti sebagian besar skor siswa yang dibelajarkan dengan pembelajaran langsung berada di bawah rata-rata dan tergolong sedang dapat dilihat pada gambar di bawah ini.

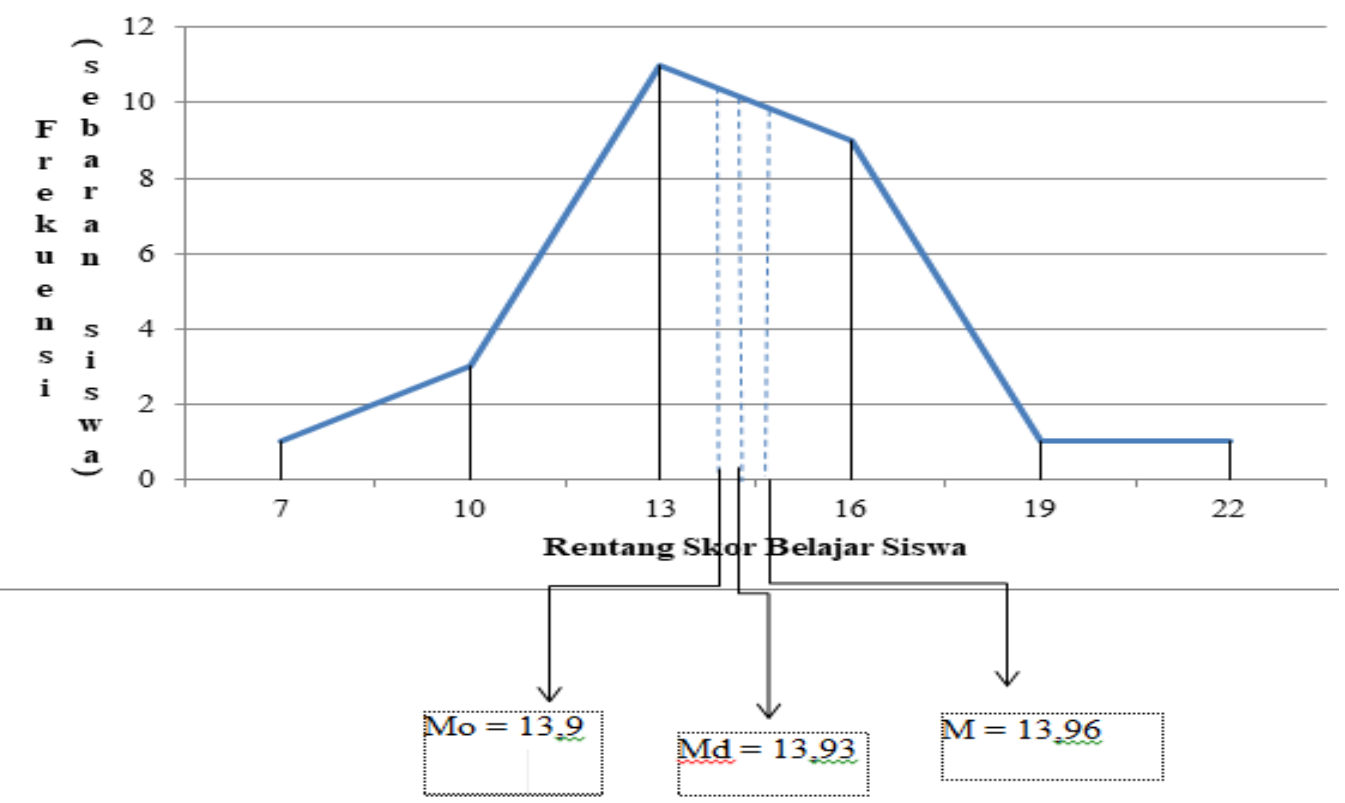

Gambar 2. Poligon Data Hasil Belajar Kelompok Kontrol

Berdasarkan penjelasan di atas menunjukkan bahwa hasil belajar ilmu pengetahuan alam dengan menggunakan model pembelajaran Kooperatif Script lebih tinggi dibandingkan dengan hasil belajar ilmu pengetahuan alam siswa yang dibelajarkan dengan pembelajaran langsung. Selain beberapa hal yang telah 
dipaparkan di atas, perbedaan yang signifikan hasil belajar IPA siswa juga bisa dilihat melalui tes evaluasi yang diberikan oleh guru kepada siswa setiap akhir pertemuan (pertemuan1-7). Dari hasil tes evaluasi yang diberikan terlihat hasil belajar IPA kelompok siswa yang dibelajarkan menggunakan model pembelajaran Kooperatif Script lebih tinggi dan mengalami peningkatan dibandingkan kelompok siswa yang dibelajarkan menggunakan pembelajaran langsung. peningkatan nilai disajikan dalam grafik histogram seperti gambar 3 di bawah ini.

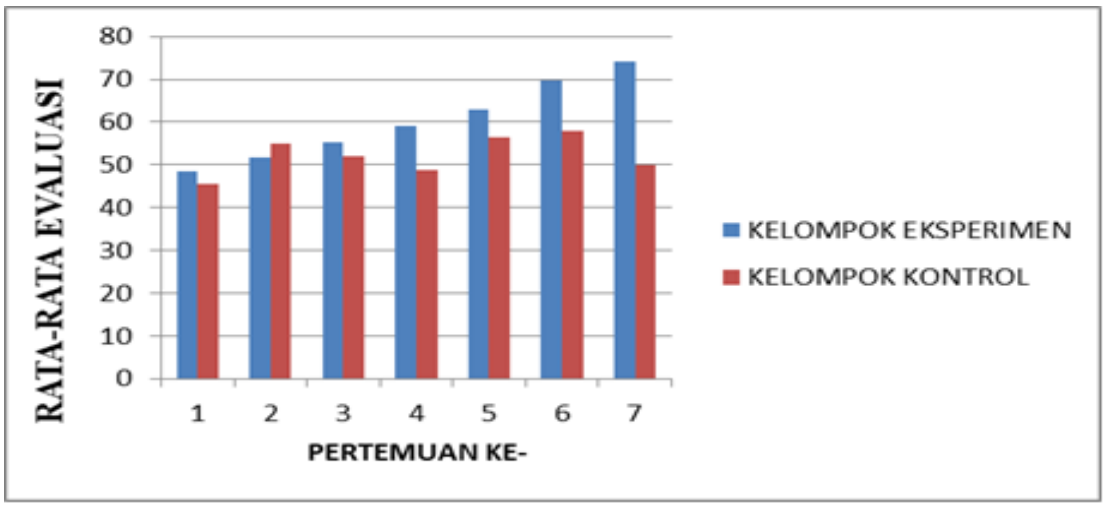

Gambar 3 Grafik Histogram Rata-rata Nilai Evaluasi

Berdasarkan grafik histogram di atas, dapat dilihat rata-rata nilai evaluasi siswa kelompok eksperimen dari pertemuan pertama sampai pertemuan ketujuh mengalami peningkatan secara signifikan. Sedangkan ratarata nilai evaluasi siswa pada kelompok kontrol dari pertemuan pertama sampai pertemuan ketujuh tidak mengalami peningkatan secara signifikan. Hal ini disebabkan karena adanya perbedaan perlakuan dalam proses pembelajaran antara siswa kelompok eksperimen dan siswa kelompok kontrol.

Selanjutnya akan dilakukan uji prasyarat yaitu uji normalitas dan uji homogenitas varians dan dilanjutkan dengan uji hipotesis. Uji normalitas sebaran data dilakukan terhadap hasil post-test kelompok eksperimen dan kelompok kontrol. Normalitas sebaran data diuji dengan menggunakan rumus Chi-Kuadrat dengan kriteria pengujian data distribusi normal jika $\mathrm{X}^{2}{ }_{\text {hitung }}<\mathrm{X}^{2}$ tabel pada taraf signifikan $5 \%$ dan derajat kebebasan dk $=$ (jumlah kelas-parameter-1). Berdasarkan hasil perhitungan dengan menggunakan rumus Chi-Kuadrat diperoleh harga $\mathrm{X}^{2}$ hitung hasil post-test kelompok eksperimen sebesar 5,85 dan $\mathrm{X}_{\text {tabel }}^{2}$ dengan derajat kebebasan $\mathrm{dk}=3$ pada taraf signifikan 5\% adalah 7,815. Hal ini berarti $\mathrm{X}_{\text {hitung }}$ hasil post-test kelompok eksperimen lebih kecil dari $\mathrm{X}_{\text {tabel }}^{2}$ yaitu $5,85<7,815$. Sehingga data hasil post-test kelompok eksperimen berdistribusi normal. Sedangkan diperoleh harga $\mathrm{X}_{\text {hitung }}^{2}$ hasil post-test kelompok kontrol sebesar 3,18 dan $\mathrm{X}_{\text {tabel }}^{2}$ dengan derajat kebebasan $\mathrm{dk}=3$ pada taraf signifikan $5 \%$ adalah 7,815 . Hal ini berarti $\mathrm{X}_{\text {hitung }}$ hasil post-test kelompok kontrol lebih kecil dari $\mathrm{X}^{2}$ tabel yaitu 3,18<7,815. Sehingga data hasil post-test kelompok kontrol berdistribusi normal.

Selanjutnya dilakukan uji homogenitas. Uji homogenitas ini dilakukan untuk mengetahui data dari kedua kelompok homogen atau tidak. Diketahui harga $F_{\text {hitung }}$ sebesar 1,92 sedangkan $F_{\text {tabel }}$ dengan db $b_{\text {pembilang }}=28-1=$ 27 dan $\mathrm{db}_{\text {penyebut }}=26-1=25$, pada taraf signifikan $5 \%$ adalah 1,94 . Hal ini berarti Fhitung lebih kecil dari pada Ftabel $(1,92<1,94)$ sehingga dapat dinyatakan bahwa varians data hasil post-test kelompok eksperimen dan kontrol adalah homogen (H0 diterima).

Setelah uji normalitas dan uji homogenitas dilakukan uji hipotesis. Hipotesisi yang diuji adalah terdapat perbedaan hasil belajar IPA kelompok siswa yang dibelajarkan dengan menggunakan model Kooperatif Script dengan kelompok siswa yang dibelajarkan dengan menggunakan pembelajaran langsung pada siswa kelas V SD di Gugus IV Kecamatan Rendang tahun ajaran 2017/2018.

Rumus yang digunakan dalam pengujian hipotesis adalah rumus polled varians, karena $\mathrm{n} 1 \neq \mathrm{n} 2$. Hasil analisis Uji-t dengan rumus polled varians diperoleh thitung sebesar 5,53 sedangkan ttabel dengan db $=54$ pada taraf signifikan 5\% adalah 2,021. Rangkuman hasil perhitungan disajikan pada tabel 2.

Tabel 2. Rangkuman Uji Hipotesis

\begin{tabular}{|c|c|c|c|c|c|c|}
\hline $\begin{array}{c}\text { Kelompok } \\
\text { Data } \\
\text { Motivasi } \\
\text { Belajar IPS }\end{array}$ & Varians $\left(\mathrm{s}^{2}\right)$ & $\mathrm{N}$ & $\begin{array}{c}\mathrm{Db} \\
\left(\mathrm{n}_{1}+\mathrm{n}_{2}-2\right)\end{array}$ & $\mathrm{t}_{\text {hitung }}$ & $\begin{array}{c}\mathrm{t}_{\text {tabel }} \text { dengan } \\
\text { taraf } \\
\text { signifikansi } \\
5 \%\end{array}$ & Kesimpulan \\
\hline $\begin{array}{l}\text { Kelompok } \\
\text { Eksperimen }\end{array}$ & 21,16 & 28 & \multirow[t]{2}{*}{52} & \multirow{2}{*}{5,53} & \multirow{2}{*}{2,021} & \multirow{2}{*}{$\begin{array}{l}\mathrm{t}_{\text {hitung }}>\mathrm{t}_{\text {tabel }} \\
\left(\mathrm{H}_{0} \text { ditolak }\right)\end{array}$} \\
\hline $\begin{array}{l}\text { Kelompok } \\
\text { Kontrol }\end{array}$ & 11,02 & 26 & & & & \\
\hline
\end{tabular}


Hasil perhitungan uji-t diperoleh thitung sebesar 5,53. Untuk mengetahui signifikansinya maka perlu dibandingkan dengan nilai $\mathrm{t}_{\text {tabel }}, \mathrm{db}=\mathrm{n} 1+\mathrm{n} 2-2=28+26-2=52$ dan taraf signifikansi $5 \%$ diperoleh nilai ttabel yaitu 2,021. Karena nilai $t_{\text {hitung }}>t_{\text {tabel }}(5,53>2,021)$, sehingga H0 ditolak dan H1 diterima. Maka dapat ditarik kesimpulan bahwa terdapat perbedaan hasil belajar ilmu pengetahuan alam antara siswa yang dibelajarkan dengan menggunakan model pembelajaran Kooperatif Script dengan kelompok siswa yang dibelajarkan dengan pembelajaran langsung pada siswa kelas V SD di Gugus IV Kecamatan Rendang tahun pelajaran 2017/2018. Perbedaan yang signifikan menunjukkan adanya pengaruh model pembelajaran kooperatif script terhadap hasil belajar Ilmu Pengetahuan Alam Siswa Kelas V SD di Gugus IV Kecamatan Rendang tahun pelajaran 2017/2018.

Berdasarkan deskripsi data hasil penelitian, kelompok siswa yang mengikuti pembelajaran dengan menggunakan model pembelajaran Kooperatif Script memiliki hasil belajar yang lebih tinggi dibandingkan dengan kelompok siswa yang dibelajarkan dengan pembelajaran langsung. Tinjauan ini didasarkan pada rata-rata kelompok siswa yang dibelajarkan dengan model pembelajaran Kooperatif Script adalah sebesar 20,03 dan ratarata kelompok siswa yang dibelajarkan dengan model pembelajaran langsung adalah sebesar 13,96. Hal ini berarti, terdapat perbedaan hasil belajar ilmu pengetahuan alam antara kelompok siswa yang dibelajarkan menggunakan model pembelajaran Kooperatif Script dan kelompok siswa yang dibelajarkan dengan menggunakan pembelajaran langsung. Perbedaan tersebut disebabkan oleh adanya perlakuan yang diberikan dalam kegiatan pembelajaran. Perbedaan tersebut juga dipengaruhi beberapa hal yaitu sebagai berikut.

Pertama, penerapan model pembelajaran Kooperatif Script mengajak siswa untuk belajar bersama pasangan dan saling bertukar pikiran, sehingga siswa lebih antusias dalam mengikuti pembelajaran. Dalam proses pembelajaran siswa lebih memiliki tanggung jawab untuk belajar, karena siswa dirangsang untuk membuat ringkasan. Penyampaian ringkasan yang telah dibuat melatih kemampuan siswa dalam mengemukakan pendapat, karena siswa memiliki kesempatan yang sama dalam menyampaikan pendapat. Pembelajaran dengan menggunakan model Kooperatif Script memberikan kesempatan bagi siswa menanyakan hal-hal yang kurang jelas bersama anggota kelompoknya. Pembelajaran ini membuat siswa berpikir lebih aktif. Selain itu, siswa dapat mengembangkan keberanian dalam menjawab dan mengemukakan pendapat.

Dengan demikian, penguasaan materi siswa meningkat sehingga hasil belajar siswa menjadi lebih baik dengan adanya interaksi antara siswa satu dengan siswa lainnya sehingga suasana kelas terlihat terlihat lebih hidup dan kondusif. Hal ini sesuai dengan pendapat Huda (2014:213) menyatakan "pembelajaran dengan menggunakan model Kooperatif Script bertujuan untuk membantu siswa berpikir secara sistematis dan berkonsentrasi penuh pada materi pelajaran. Siswa juga dilatih untuk saling bekerja sama satu sama lain dalam suasana yang menyenangkan". Model ini diawali dengan membagi kelompok secara berpasangan. Di dalam kelompok tersebut siswa bekerja sama menyelesaikan permasalahan-permasalahan yang diberikan oleh guru. Setiap anggota dalam kelompok harus menguasai materi yang telah diberikan guru dan dalam situasi tersebut akan tercipta kerja sama antara anggota kelompok.

Kedua, pembelajaran menggunakan model Kooperatif Script yang di desain dengan membentuk kelompok agar siswa bekerja sama dalam menyelesaikan permasalahan yang diberikan. Melalui kegiatan diskusi kelompok siswa secara aktif dan antusias untuk memecahkan masalah yang dihadapi dalam proses pembelajaran ilmu pengetahuan alam. Siswa yang belum mengerti dapat bertanya langsung dengan teman kelompok, sehingga menumbuhkan rasa ingin tahu yang tinggi.

Ketiga, adanya variasi sumber belajar membuat siswa diarahkan terlibat penuh dalam proses pembelajaran. Keterlibatan siswa dalam proses pembelajaran mengarahkan siswa mencari tahu sendiri materi yang dipelajari, sehingga menciptakan daya ingat yang lebih kuat terhadap materi yang dipelajari. Kerja keras pun akan dapat dipupuk dari karakteristik tersebut. Dengan demikian, model pembelajaran Kooperatif Script dapat berpengaruh terhadap hasil belajar siswa. Hal ini didukung oleh penelitian yang dilakukan oleh Budiada (2013) yang menyatakan "bahwa model pembelajaran Kooperatif Script dapat meningkatkan aktivitas belajar siswa dalam pembelajaran geografi.

Temuan hasil penelitian di atas sesuai dengan temuan yang dilakukan oleh Fathkurofi (2015) menunjukkan bahwa penggunaan model Kooperatif Script dengan metode praktikum juga terbukti berpengaruh terhadap kemampuan representasi verbal fisika siswa. Sejalan dengan Fathkurofi (2015) penelitian yang sama juga dilakukan oleh Asriyani (2013) hasil penelitiannya menunjukkan bahwa ada perbedaan hasil belajar ilmu pengetahuan alam antara kelompok siswa dengan menggunakan model pembelajaran Kooperatif Script berbantuan peta pikiran dan kelompok siswa yang dibelajarkan dengan model konvensional.

Selain beberapa hal yang telah dipaparkan di atas, perbedaan yang signifikan hasil belajar ilmu pengetahuan alam siswa juga bisa dilihat melalui tes evaluasi yang diberikan oleh guru kepada siswa setiap akhir pertemuan. Dari hasil tes evaluasi yang diberikan terlihat hasil belajar ilmu pengetahuan alam kelompok siswa yang dibelajarkan menggunakan model pembelajaran Kooperatif Script lebih tinggi dan mengalami peningkatan dibandingkan kelompok siswa yang dibelajarkan menggunakan pembelajaran langsung.

Berdasarkan pada pemaparan di atas, dapat disimpulkan bahwa terdapat perbedaan yang signifikan hasil belajar ilmu pengetahuan alam siswa antara kelompok siswa yang dibelajarkan dengan menggunakan model pembelajaran Kooperatif Script dengan kelompok siswa yang dibelajarkan dengan pembelajaran langsung. 
Dengan demikian, model pembelajaran Kooperatif Script berpengaruh positif terhadap hasil belajar siswa sehingga hasil belajar dapat meningkat.

\section{Simpulan}

Simpulan dari penelitian ini adalah terdapat perbedaan hasil belajar ilmu pengetahuan alam antara kelompok siswa yang dibelajarkan dengan model pembelajaran Kooperatif Script dengan siswa yang dibelajarkan dengan pembelajaran langsung siswa kelas V SD di Gugus IV Kecamatan Rendang, Kabupaten Karangasem tahu pelajaran 2017/2018. Dengan demikian, maka model pembelajaran Kooperatif Script berpengaruh positif terhadap hasil belajar ilmu pengetahuan alam siswa.

Saran yang dapat diajukann dalam penelitian ini yaitu (1) bagi siswa sebaiknya lebih giat dan rajin membaca untuk dapat memperoleh hasil belajar yang lebih baik dan mampu mengaplikasikan pengetahuannya dalam kehidupan sehari-hari, (2) guru hendaknya mencoba mengembangkan kompetensinya dalam hal mengelola pembelajaran untuk mewujudkan kegiatan pembelajaran yang menyenangkan, efektif, dan mampu meningkatkan hasil belajar siswa, (3) kepala sekolah hendaknya mengajak guru-guru untuk mengikuti seminar atau pelatihan mengenai upaya meningkatkan hasil belajar siswa dengan menggunakan model pembelajaran yang inovatif. (4) penelitian ini hanya dibatasi pada hasil belajar siswa dalam ranah kognitif. Kepada peneliti lain yang ingin melakukan penelitian selanjutnya hendaknya mengembangkan hasil penelitian dalam ranah afektif dan psikomotor untuk perbaikan serta penyempurnaan penelitian yang akan dilaksanakan.

\section{Daftar Pustaka}

Agung, A. A. G. 2014. Metodologi Penelitian Pendidikan. Malang: Aditya. Media Publishing.

Antara, P. A. \& Agus, I Gst. K. A. (2011). "Peningkatan Kemampuan Berpikir Kritis Anak Melalui Metode Bermain Peran”. Jurusan Pedagogik - FIP - UPI dan Asosiasi Pendidikan Profesi Guru SD, Nomor 2 , (hlm. 245-2567).

Asriyani, K. D., Sedanayasa, G., \& Pudjawan, K. 2013. "Pengaruh Model Pembelajaran Kooperatif Script Berbantuan Peta Pikiran Terhadap Hasil Belajar IPA Siswa Kelas IV SD Negeri Busung Biu". Tersedia pada https://ejournal.undiksha.ac.id/index.php/JJPGSD/articel/view/676 diunduh pada tanggal 03 Januari 2018.

Budiada, N., Suryadi, M., \& Suartha, I K. 2013. "Penerapan Model Pembelajaran Kooperatif Tipe Script Pada Mata Pelajaran Geografi Dalam Peningkatan Aktivitas Dan Hasil Belajar Siswa Kelas XI IPS 2 SMA Jagadhita Amlapura Kecamatan Karangaswm Kabupaten Karangasem". Tersedia pada https://ejournal.undiksha.ac.id/index.php/JJPG/articel/View/1999 diunduh pada tanggal 03 Januari 2018.

Fatkhurofi, I., Mahardika, I K., \& Lesmono, A. D. 2015. "Pengaruh Model Pembelajaran Kooperatif Tipe Script Dengan Metode Praktikum Terhadap Kemampuan Multirefresentasi Siswa Dalam Pembelajaran Fisik Kelas X Di SMA Muhammadiyah 3 Jember". Tersdia pada https://jurnal.unej.ac.id/index.php/JPF/articel/view/1876 diunduh pada tanggal 03 Januari 2018.

Huda, M. 2014. Model-model Pengajaran dan Pembelajaran. Yogyakarta: Pustaka Pelajar.

Samatowa, U. 2010. Pembelajaran IPA di Sekolah Dasar. Jakarta: PT Indeks.

Suranata, K., \& Susiani, K. (2017), Implementasi Metode Sokratik Melalui Lesson Study untuk Meningkatkan Keterampilan Berpikir Kritis Mahasiswa. Volume 1, No.1, (hlm. 27-40)

Syaifurahman. 2013. Manajemen dalam Pembelajaran. Jakarta: PT indeks. 